\title{
Frequency of Dental Fluorosis in Population Drinking Water with High Fluoride Level in Thar
}

\author{
Iftekhar Ahmed ${ }^{1}$ \\ Anwar Ali ${ }^{2}$ \\ Marium Zaheer ${ }^{3}$ \\ Ibraj Fatima ${ }^{4}$ \\ Nazeer Khan ${ }^{5}$
}

\author{
MBBS, MCPS, FCPS \\ BDS, FDSRCS \\ BDS, MDS
}

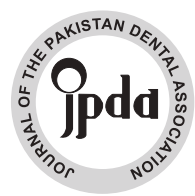

PhD

OBJECTIVE: The objective of this study is to see the frequency of dental fluorosis in exposed area (Sammo Rind village of Thar District) and in unexposed area of Gadap town of Karachi and to find the association of fluoride level with dental fluorosis in both groups.

METHODOLOGY: The water samples were taken from both the sites and fluoride estimation in water and geometrical, was determined using Fluoride Ion Selective Electrode (FISE) method. By random selection 121 subjects from Sammo Rind village and 121 controls from Gadap Town Karachi were included in study after informed consent. The participants were clinically examined by an expert university teacher dentist in proper dental setups in examination lights.

RESULTS: A frequency of dental fluorosis of $100 \%$ was found among the study subjects with fluoride content as high as 6$8 \mathrm{mg} / \mathrm{dl}$ as compared to prevalence of dental fluorosis $17.4 \%$ in unexposed group with water fluoride content as low as $0.30 \mathrm{mg} / \mathrm{dl}$. CONCLUSIONS: The high level of underground water fluoride level and cent per cent dental fluorosis in Thar area is an alarming situation that should be addressed immediately at national level.

KEYWORDS: Exposed area, Dental Flurosis, Fluoride Level, Water Sample

HOW TO CITE: Ahmed I, Ali A, Zaheer M, Fatima I, Khan N. Frequency of dental fluorosis in population drinking water with high fluoride level in Thar. J Pak Dent Assoc 2020;29(4):259-263.

DOI: https://doi.org/10.25301/JPDA.294.259

Received: 19 June 2020, Accepted: 13 August 2020

\section{INTRODUCTION}

$\mathrm{T}$ har is the largest desert of Pakistan and seventh largest in the world. ${ }^{1}$ This desert has the blessing of being the only fertile desert in the world where the rainfall brings the dead land to life. That is the reason why people live not only in the outskirts of desert but also in the desert area. ${ }^{2}$ This semi-arid area seems not completely xeric because of the average rainfall of 200-300 mm which is usually erratic and non-consistent. ${ }^{3}$ The natural disaster is not always the drought but the poluuted water when available contains lots of impurities and sediments. ${ }^{4}$ This leads the human growth and development towards imbalanced

1. Professor, Department of General Medicine, D.I.M.C, Dow University of Health Sciences, Karachi.

2. Professor, Department of Ora Sugery, Dr Ishrat ul Ebad Khan Institute of Oral Health Sciences Dow University of Health Sciences, Karachi.

3. Assistant Professor, Department of Oral Pathology, Dr Ishrat ul Ebad Khan Institute of Oral Health Sciences Dow University of Health Sciences, Karachi.

4. MBBS (student) Undergraduate Student, Department of General Medicine, D.I.M.C, Dow University of Health Sciences, Karachi.

5. Professor, Department of Biostatistics, Jinnah Sindh Medical University.

Corresponding author: "Dr. Iftekhar Ahmed" < dr_iftekharahmed@ hotmail.com > proportions in majority of aspects of health. Thar desert is 120 meter elevated from sea level. The geographical proximity of the Great Rann of Kutch (the largest salt marsh) and Arabian Sea in the South of Thar Desert render the underground water of Thar a marine environment. ${ }^{5}$ Furthermore, the alluvial plains of Indus River and the coast make the underground water more salty. ${ }^{6}$ The volcano in the region of Rajisthan may be the source. Thar is a tropical area with maximum temperature as high as $48^{\circ} \mathrm{C}^{1}$ thus giving the clue of presence of coal beneath its burning lands.

Thar is the largest district of Sind. ${ }^{4}$ It has a total population of 1.65 million scattered over an area of $19,638 \mathrm{~km}^{2}$. Water, the most treasurable natural resource that is gifted to human beings, is under constantly increasing intimidation in this area. Therefore, inadequate access to safe drinking water has become the most critical and the most challenging environmental problem. Throughout history, people of this region have used groundwater as a source of drinking water and not only them, more than half of the world's population depends on it for existence. Groundwater constitutes $97 \%$ of global freshwater and in many regions, groundwater springs 
are the single principal source for serving drinking water. ${ }^{7}$ Thus the accessibility of uncontaminated groundwater is most vital, as it serves as the critical component in every sphere of human life. Scarcity of drinking water and moreover the increased mineral and ion concentration in water are crucial factors in keeping the health of Thar people blow the level of satisfaction. For example the higher concentration of nitrate in groundwater is hazardous, predominantly for newborn babies affected by 'blue baby syndrome. ${ }^{8}$ The local population pulls the underground water from wells for their drinking, cooking and everyday utilization1. The wells can be as deep as 3-90 $\mathrm{m}$ and pulling of water is aided by help of camels.

One of the most crippling biochemical diseases that emerge as a result of imbalanced ion concentration in water is fluorosis. ${ }^{9}$ That is caused by excess intake of fluoride ion. Along with many minerals present in water, one of the most important ions is fluoride ion. ${ }^{9}$ Fluoride is the ion of fluorine, the 17th most plentiful and most electronegative element on ecosphere. It is highly reactive that's why it is found in combination of other elements such as calcium fluoride or fluorspar. Rocks and soil are the main reservoir of fluoride that leaches out in the underground water. Drinking water, food, tea, air, medicaments and cosmetics are the sources of fluoride exposure in human beings. The drinking water or fresh water fluoride level (0.01-0.3 parts per million (ppm) is different from sea water fluoride level (1.2-1.5 ppm). Concentration of fluoride in water depends upon the temperature that is very high in Thar Desert and sedimentary rocks, lime stone, sand stones and volcano rocks present in this area. ${ }^{10}$

Fluorosis affect many systems in body primarily teeth and bones. ${ }^{11}$ The other systems include nervous system, reproductive system, liver, kidneys and cardiovascular system. Long term intake of fluoride during tooth development leads to enamel fluorosis. There is a linear relationship in dose and response. The recommended fluoride content in drinking water should not be more than 1 parts per million (ppm). ${ }^{12}$ It is of interest that the fluorosis occurs due to local effects of fluoride on the mineralizing tooth germ, predominantly the maturation stage of enamel formation that is up to the age of 8 years. ${ }^{12}$ Fluorosis clinical spectrum ranges from mild discoloration of tooth surface to severe staining and pitting. ${ }^{12}$

There have been various studies mentioning the excessive level of fluoride preset in the drinking water of Thar district. ${ }^{1,13-16}$ The native individuals are at high risk of developing dental fluorosis. However, the literature search reveals scarcity of data on dental fluorosis. ${ }^{17,18}$ prevalence and its characteristics in Thar district. Therefore we design a study to evaluate the fluoride estimation in drinking water and geometrical samples and to investigate the dental changes associated with increased fluoride intake that is the dental fluorosis in Thar.

\section{METHODOLOGY}

This was a descriptive comparative cross-sectional study. Ethical approval was obtained by the Institutional Review Board of Dow University of Health Sciences (Ph-D-06/ERB50/DUHS-08. The study was approved by Institutional Review Board, Dow University of Health Sciences. The study was conducted for dental florosis and sample size was calculated from WHO sample size calculator accordingly. A total of 242 participants were included 121 in each group. List of residents was made with the help of map of houses. The study site for exposed was the village Sammo Rind that is situated $40 \mathrm{~km}$ in the South East of Chachro Town in Thar District. The unexposed group comprised of age and sex matched individuals from three villages (Pathan Goth, Screane Goth and Bi Khori Goth) of Gadap Town. Gadap Town is situated in North West Karachi along the Hub River at the provincial border between Sindh and Baluchistan. Using systematic random sampling every fifteenth resident was recruited and consent was taken. If consent was refused then next fifteenth resident was called upon. Likewise for the control gunexposed group, one out of thirty residents (age and sex matched) of three villages of Gadap Town was included. The study subjects' of age of 12 years and above were brought to Karachi from the case and control sites. Both male and female subjects, living in the area since birth were included. The only exclusion criterion was the immigrants of other areas. Complete history with thorough clinical examination in proper clinical settings were conducted in a tertiary care hospital in Karachi. Oral cavity was examined by a senior dentist in dental unit Enamel abnormalities were recorded according to Dean HT classification (Table 2) of mottled enamel diagnosis and Thylstrup \& Fejerskov Index (TF index) (Table 3). Moreover photographs were also taken. Findings were recorded in printed Performa. Samples of underground water were taken from study and unexposed group sites. For fluoride estimation in water and geometrical (rock, soil, clay etc) samples, Fluoride Ion Selective Electrode (FISE) method was applied. The total Ionic Strength Adjustment Buffer (TISAB) was used for $\mathrm{pH}$ and fragmentation of aluminum fluoride complexes which might otherwise lessen the fluoride activity.

\section{RESULT}

\section{Data Analysis}

A data base was developed on SPSS for windows version 22.0. Mean and standard deviation were calculated for 
quantitative variables like age, fluoride level etc.. A frequency with percentages was presented for qualitative variables like gender, fluorosis etc. Chi square test was applied and $\mathrm{P}$-values $<0.05$ was taken as statistically significant.

\section{Demographic Features}

Of total 242 subjects, there were 121 exposed subjects and 121 unexposed subject. The mean age in exposed was $33.82 \pm 14.10$ years while the mean age in unexposed was found to be $33.33 \pm 11.67$ years (Table- 4 ). The mean difference

Table 1: Changes according to Deans index of the Cases and Controls

\begin{tabular}{|l|l|l|l|l|l|}
\hline \multirow{2}{*}{$\begin{array}{l}\text { Changes } \\
\text { according to } \\
\text { dean index }\end{array}$} & \multicolumn{2}{|l|}{ EXPOSED } & \multicolumn{2}{|l|}{ UNEXPOSED } & P Value \\
\cline { 2 - 6 } & FREQUENCY & PERCENT & FREQUENCY & PERCENT & \\
\hline NORMAL & 0 & 0 & 100 & 82.6 & \\
\hline $\begin{array}{l}\text { QUESTIONABL } \\
\text { E }\end{array}$ & 2 & 1.7 & 8 & 6.6 & \\
\hline VERY MILD & 9 & 7.4 & 7 & 5.8 & $<0.05$ \\
\hline MILD & 18 & 14.9 & 4 & 3.3 & \\
\hline MODERATE & 69 & 57 & 1 & 0.8 & \\
\hline SEVERE & 23 & 19 & 1 & 0.8 & \\
\hline TOTAL & 121 & 100 & 121 & 100 & \\
\hline
\end{tabular}

Table 2: Dean's Index Classification

\begin{tabular}{|c|c|}
\hline & Dean's Index \\
\hline Classification & Characteristics of enamel \\
\hline Normal & Smooth, glossy, pale creamy-white translucent surface \\
\hline Questionable & A few white flecks or white spots \\
\hline Very Mild & $\begin{array}{l}\text { Small opaque, paper white areas covering less than } 25 \% \text { of the } \\
\text { tooth surface }\end{array}$ \\
\hline Mild & Opaque white areas covering less than $50 \%$ of the tooth surface \\
\hline Moderate & $\begin{array}{l}\text { All tooth surfaces affected; marked wear on biting surfaces; } \\
\text { brown stain may be present }\end{array}$ \\
\hline Severe & $\begin{array}{l}\text { All tooth surfaces affected; discrete or confluent pitting; brown } \\
\text { stain present }\end{array}$ \\
\hline
\end{tabular}

was insignificant ( $\mathrm{p}=0.7686$ ), Moreover, the total number of males in exposed subject was 90 while the total number of males in unexposed subjects was found to be 84 , which constitute about $74.4 \%$ and $69.4 \%$ respectively. Majority of the exposed subjects $(n=88 ; 72.7 \%)$ and unexposed $(n=96 ; 79.3 \%)$ were married (Table-5). While the occupation of most of the exposed $(n=49 ; 40.5 \%)$ and unexposed subject $(n=43 ; 35.5 \%)$ were farming. However, responsibility of majority females were taking care of household constituting $25.6 \%(n=31)$ and $26.2 \%(n=32)$ of cases and controls respectively (Table-6).
Table 2a: Changes according to T.F Smooth Surfaces index

\begin{tabular}{|c|c|c|c|c|c|}
\hline & \multicolumn{2}{|c|}{ Exposed } & \multicolumn{2}{|c|}{ Unexposed } & \multirow[t]{2}{*}{ p valuc } \\
\hline & Frequency & Percent & Frequency & Percent & \\
\hline $\mathbf{0}$ & 0 & o & 98 & 81 & \multirow{9}{*}{$<0.05$} \\
\hline 1 & 1 & 0.8 & 8 & 6.6 & \\
\hline 2 & 5 & 4.1 & 8 & 6.6 & \\
\hline 3 & 10 & 8.3 & 2 & 1.7 & \\
\hline 4 & 25 & 20.7 & 2 & 1.7 & \\
\hline 5 & 41 & 33.9 & 1 & 0.8 & \\
\hline 6 & 23 & 19 & 1 & 0.8 & \\
\hline 7 & 12 & 9.9 & $\mathbf{0}$ & 0 & \\
\hline 8 & 4 & 3.3 & 1 & 0.8 & \\
\hline Total & 121 & 100 & 121 & 100 & \\
\hline
\end{tabular}

Table 2b: Changes according to T.F Occlusal Surfaces index

\begin{tabular}{|c|c|c|c|c|c|}
\hline & \multicolumn{2}{|c|}{ Exposed } & \multicolumn{2}{|c|}{ Unexposed } & \multirow[t]{2}{*}{ p value } \\
\hline & Frequency & Percent & Frequency & Percent & \\
\hline 0 & - & - & 98 & 98 & \multirow{9}{*}{$<0.05$} \\
\hline 1 & 1 & 0.8 & 8 & 8 & \\
\hline 2 & 7 & 5.8 & 8 & 8 & \\
\hline 3 & 10 & 8.3 & 2 & 2 & \\
\hline 4 & 24 & 19.8 & 2 & 2 & \\
\hline 5 & 40 & 33.1 & 1 & 1 & \\
\hline 6 & 23 & 19 & 1 & 1 & \\
\hline 7 & 12 & 9.9 & 0 & 0 & \\
\hline 8 & 4 & 3.3 & 1 & 1 & \\
\hline Total & 121 & 100 & 121 & 121 & \\
\hline
\end{tabular}

Table 3: Clinical Criteria and Scoring for the TFI (Thylstrup-Fejerskov Index)

\begin{tabular}{|c|c|}
\hline Score & Criteria \\
\hline $\mathbf{0}$ & Normal translucency of enamel remains after prolonged air-drying \\
\hline 1 & Narrow white lines corresponding to the perikymata. \\
\hline \multirow{2}{*}{2} & $\begin{array}{l}\text { Smooth surfaces: More pronounced lines of opacity that follow the perikymata. } \\
\text { Occasionally confluence of adjacent lines. }\end{array}$ \\
\hline & $\begin{array}{l}\text { Occlusal surfaces: Scattered areas of opacity }<2 \mathrm{~mm} \text { in diameter and pronounced opacity } \\
\text { of cuspal ridges. }\end{array}$ \\
\hline 3 & $\begin{array}{l}\text { Smooth surfaces: Merging and irregular cloudy areas of opacity. Accentuated drawing of } \\
\text { perikymata often visible between opacities. } \\
\text { Occlusal surfaces: Confluent areas of marked opacity. Worn areas appear almost normal } \\
\text { but usually circumscribed by a rim of opaque enamel. }\end{array}$ \\
\hline 4 & $\begin{array}{l}\text { Smooth surfaces: The entire surface exhibits marked opacity or appears chalky white. } \\
\text { Parts of surface exposed to attrition appear less affected. } \\
\text { Occlusal surfaces: Entire surface exhibits marked opacity. Attrition is often pronounced } \\
\text { shortly after eruption. }\end{array}$ \\
\hline 5 & $\begin{array}{l}\text { Smooth surfaces and occlusal surfaces: Entire surface displays marked opacity wtih focal } \\
\text { loss of outermost enamel (pits) }<2 \mathrm{~mm} \text { in diameter. }\end{array}$ \\
\hline 6 & $\begin{array}{l}\text { Smooth surfaces: Pits are regularly arranged in horizontal bands }<2 \mathrm{~mm} \text { in vertical } \\
\text { extension. Occlusal surfaces: Confluent areas }<3 \mathrm{~mm} \text { in diameter exhibit loss of enamel. } \\
\text { Marked attrition. }\end{array}$ \\
\hline 7 & $\begin{array}{l}\text { Smooth surfaces: Loss of outermost enamel in irregular areas involving }<1 / 2 \text { of entire } \\
\text { surface. } \\
\text { Occlusal surfaces: Changes in the morphology caused by merging pits and marked } \\
\text { attrition. }\end{array}$ \\
\hline 8 & Smooth and occlusal surfaces: Loss of outermost enamel involving $>1 / 2$ of surface. \\
\hline 9 & $\begin{array}{l}\text { Smooth and occlusal surfaces: Loss of main part of enamel with change in anatomic } \\
\text { appearance of surface. Cervical rim of almost unaffected enamel is often noted. }\end{array}$ \\
\hline
\end{tabular}

\section{Dental Changes}

Out of 121 study subjects, all 121 subjects were found to have dental fluorosis that is $100 \%$. In contrast, $82.6 \%$ in control area had normal teeth. According to Dean Index; 

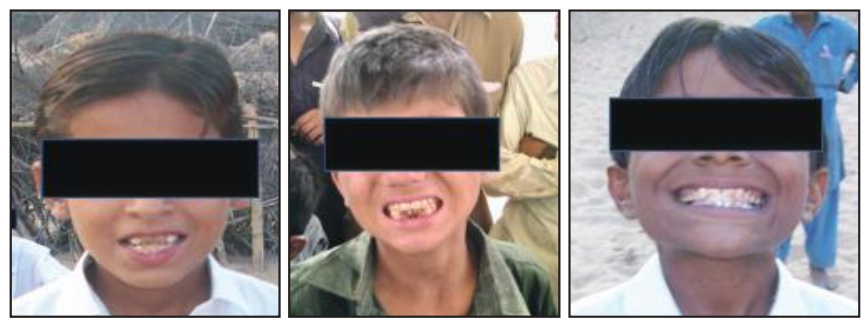

Dental fluorosis in a 14 years old boy

mild, moderate and severe changes were seen in 18 (14.9\%), $69(57 \%)$ and 23(19\%) exposed subject respectively (Table 1). Ch isqaure test was applied and $P$ value found to be $<0.05$. Given the $\mathrm{p}$ value $<0.05$ there is significant association between exposure to water having high flouride content and characterstics of enamel according to Dean index of classification. Moreover, evaluation according to T.F index grade for smooth surface index in 2, 3, 4, 5, 6, 7 and 8 changes were seen in $5(4.1 \%), 10(8.3 \%), 25(20.7 \%)$, $41(33.90 \%), 23(19 \%), 12(9.9 \%)$ and 4(3.3\%), respectively with $\mathrm{p}$ value $<0.05$ (Table 7a). TF scores for occlusal surface index for the same level were shown in table 2 b.Both T.F smooth surface index and occlusal surface index have statistically significant association with exposure group as per given $\mathrm{p}$ value of $<0.05$.

\section{Water fluoride estimation}

The well water consumed by the population of Sammo Rind has been analyzed for its fluoride content and was found to be $6-8 \mathrm{mg} / \mathrm{dl}$, as compared to control area where fluoride levels are found to be $0.30 \mathrm{mg} / \mathrm{L}$. World Health Organization (WHO) recommends fluoride concentration level in drinking water at $1.5 \mathrm{mg} / \mathrm{L}$ or it can be documented as $0.8-0.9 \mathrm{ppm}$. The remaining trace elements in this area were normal.

\section{DISCUSSION}

Pakistan is one among the countries where fluorosis is endemic. Thar Desert areas of Sindh province are among the affected areas. The groundwater, especially the water in unconfined aquifers, is the main source of drinking water for people living in the rural desert areas of Sindh. Groundwater is mostly available in dug-wells, generally at the depth of 30 to 75 meters, which is brackish and highly contaminated by the presence of fluoride. A high prevalence of fluorosis is present in such areas including dental, skeletal, musculoskeletal and other forms of fluorosis.

There are numerous studies on the increased levels of fluoride in the ground water of Thar Desert. Many studies were conducted to find the prevalence of dental fluorosis in different parts of the country but there is a dearth of data on dental fluorosis in Thar Desert. Studies from Lahore, MianWali and Murdan and Quetta reported the prevalence of dental fluorosis. ${ }^{19-22}$ Study by Rizwan et al in 2012 in Lahore dental Hospital, patients coming for dental problems were examined and the frequency of dental fluorosis was found to be $12 \% .^{20}$ This result is much lower than the result of our study, may be due to level of fluoride ion in drinking water is not as high as in Thar area. Moreover, in a tertiary care hospital patients come from near and far, not confining to a particular locality. Another reason of this vast difference may the fact that rural population usually live their whole lives in same place for decades while urban life is not so static, people move from one area to another area earlier as compared to rural life, hence changing the water for drinking. Moreover, the source of water is not always ground water in urban life style. However, some portion of population get affected by ground water but other sources of fluoride for example tea, food, supplements, fluoride containing tooth pastes, mouth washes and beverages may contribute to develop fluorosis in urban population. Another study from Quetta by Sami et al reported the prevalence of dental fluorosis as $63.3 \%$ in school going children of Quetta, most of it was of moderate type. ${ }^{21}$ The prevalence rate is much higher in this study; the higher fluoride level in the region may be the cause. The prevalence found in Quetta school children was found to be close to our study result. A study conducted in MianWali and Murdan stated the prevalence of dental fluorosis as $98 \%$, this result is in approximation with our result. ${ }^{19}$ On more study with this outcome in children of 12 year of age. ${ }^{23}$ As we examined the individuals not only from the Sammo Rind village but also the unexposed group of Gadap town of Karachi, the result showed that in spite of having similarity in eating style and life style of both groups of same ethnicity, the difference in the prevalence of dental fluorosis is due to the level of ground water fluoride ion concentration. Dental fluorosis was seen in $100 \%$ of subjects and only in $17.4 \%$ in unexposed group. Mild, moderate and severe changes were seen in 18 (14.9\%), 69(57\%) and $23(19 \%)$ exposed subjects according to Dean Index of grading system of dental fluorosis respectively wheareas the severity of flourosis in unexposed group was $0.8 \%$ only the majority of the positive patient in unexposed group fall into the category of either questionable $(6.6 \%)$ or very mild (5.8\%)The well water of Sammo Rind fluoride content was found to be $6-8 \mathrm{mg} / \mathrm{dL}$, as compared to control area where fluoride levels are found to be $0.30 \mathrm{mg} / \mathrm{L}$.

\section{CONCLUSION}

Fluorosis forays the Thar Desert so hard that no person had been found to have normal healthy teeth. The frequency 
of dental flourosis is significantly high in the area where flouride level in drinking water is higher than the recommended value when compared with the population drinking water with normal flouride.

\section{REFERENCE}

1. Rafique T, Naseem S, Bhanger MI, Usmani TH. Fluoride ion contamination in the groundwater of Mithi sub-district, the Thar Desert, Pakistan. Environmental Geology. 2008;56:317-26. https://doi.org/10.1007/s00254-007-1167-y

2. Rahmani AR, Soni R. Avifaunal changes in the Indian Thar desert. Journal of arid environments. 1997;36:687-703.

https://doi.org/10.1006/jare.1996.0242

3. Lau WK, Kim KM. Fingerprinting the impacts of aerosols on longterm trends of the Indian summer monsoon regional rainfall. Geophysical Research Letters. 2010;37(16).

https://doi.org/10.1029/2010GL043255

4. Bilal M, Liaqat MU, Cheema MJM, Mahmood T, Khan Q, editors. Spatial drought monitoring in Thar desert using satellite-based drought indices and geo-informatics techniques. Multidisciplinary Digital Publishing Institute Proceedings; 2017.

https://doi.org/10.3390/ecws-2-04948

5. Bhatt HB, Gohel SD, Singh SP. Phylogeny, novel bacterial lineage and enzymatic potential of haloalkaliphilic bacteria from the saline coastal desert of Little Rann of Kutch, Gujarat, India. 3 Biotech. 2018;8(1):53.

https://doi.org/10.1007/s13205-017-1075-0

6. Edmunds WM, Smedley PL. Fluoride in natural waters. Essentials of medical geology: Springer; 2013. p. 311-36.

https://doi.org/10.1007/978-94-007-4375-5_13

7. Gleick PH, Cain NL. The world's water 2004-2005: the biennial report on freshwater resources: Island Press; 2004.

8. Soomro F, Rafique T, Michalski G, Ali SA, Naseem S, Khan MU. Occurrence and delineation of high nitrate contamination in the groundwater of Mithi sub-district, Thar Desert, Pakistan. Environmental earth sciences. 2017;76(10):355.

https://doi.org/10.1007/s12665-017-6663-0

9. Sergio R-VJ, Luilli LC, Carlos R-LJ. Fluoride: its implications for public health. 2018.

10. Khatri G, Bahura C. Flouride in ground water sources of sardarshahar city of churu District in the thar desert of rajasthan. 2017. https://doi.org/10.20959/wjpr201710-9422

11. Simon MJ, Beil FT, Riedel C, Lau G, Tomsia A, Zimmermann EA, et al. Deterioration of teeth and alveolar bone loss due to chronic environmental high-level fluoride and low calcium exposure. Clinical oral investigations. 2016;20:2361-70.

https://doi.org/10.1007/s00784-016-1727-1
12. Goodarzi F, Mahvi AH, Hosseini M, Nodehi RN, Kharazifard MJ, Parvizishad M. Fluoride concentration of drinking water and dental fluorosis: A systematic review and meta-analysis in Iran. Dental Hypotheses. 2016;7(3):81.

https://doi.org/10.4103/2155-8213.190482

13. Husain V, Nizam H, Arain GM. Arsenic and fluoride mobilization mechanism in groundwater of Indus Delta and Thar Desert, Sindh, Pakistan. Int J Econ Env Geol. 2012;3:15-23.

14. Choubisa SL. Fluoride distribution in drinking groundwater in Rajasthan, India. Curr Sci. 2018;114:1851-57. https://doi.org/10.18520/cs/v114/i09/1851-1857

15. Rafique T, Naseem S, Ozsvath D, Hussain R, Bhanger MI, Usmani TH. Geochemical controls of high fluoride groundwater in Umarkot sub-district, Thar Desert, Pakistan. Science of the Total Environment. 2015;530:271-78.

https://doi.org/10.1016/j.scitotenv.2015.05.038

16. Brahman KD, Kazi TG, Afridi HI, Naseem S, Arain SS, Ullah N. Evaluation of high levels of fluoride, arsenic species and other physicochemical parameters in underground water of two sub districts of Tharparkar, Pakistan: a multivariate study. Water research. 2013;47:1005-20.

https://doi.org/10.1016/j.watres.2012.10.042

17. Rafique T, Ahmed I, Soomro F, Khan MH, Shirin K. Fluoride Levels in Urine, Blood Plasma and Serum of People Living in an Endemic Fluorosis Area in the Thar Desert, Pakistan. Journal of the Chemical Society of Pakistan. 2015;37(6).

18. Ahmed I, Sohail S, Hussain M, Khan N, Khan MH. MRI features of spinal Fluorosis: Results of an endemic community screening. Pakistan J Med Sci. 2013;29(1):177.

https://doi.org/10.12669/pjms.291.3200

19. Siddiq K, Dost S, Naseem A, Arshad A, Ullah A. Prevalence of Dental Fluorosis in Mianwali and Mardan Districts. Journal of Cosmetics, Dermatological Sciences and Applications. 2011;1(03):106. https://doi.org/10.4236/jcdsa.2011.13016

20. Rizwan S, Rizwan M, Naveed A, Ahsan W. Incidence of dental fluorosis among the Patients visiting the university of Lahore Dental College/Hospital-A study. Pakistan Oral \& Dental Journal. 2010;30(1).

21. Sami E, Vichayanrat T, Satitvipawee P. Caries with Dental Fluorosis and Oral Health Behaviour Among 12-Year School Children in Moderate-Fluoride Drinking Water Community in Quetta, Pakistan. Pakistan Journal of the College of Physicians and Surgeons Pakistan. 2016;26:744-47.

22. Tahir M, Rasheed H. Fluoride in the drinking water of Pakistan and the possible risk of crippling fluorosis. Drinking Water Engineering and Science. 2012;5:495-514.

https://doi.org/10.5194/dwesd-5-495-2012

23.Khan AA, Whelton $\mathrm{H}$, O'Mullane D. Is the fluoride level in drinking water a gold standard for the control of dental caries? Int Dent J. 2004;54:256-60.

https://doi.org/10.1111/j.1875-595X.2004.tb00290.x 